\title{
SISTEM PENGENDALIAN MANAJEMEN DAN PERILAKU DYSFUNCTIONAL SATUAN KERJA PERANGKAT DAERAH PROVINSI BANTEN
}

\author{
Tri Lestari \\ trilestari.untirta@gmail.com, Jurusan Akuntansi, Universitas Sultan Ageng Tirtayasa,Banten, \\ Indonesia \\ Lili Sugeng Wiyantoro \\ li2k_feuntirta@ymail.com, Jurusan Akuntansi, Universitas Sultan Ageng Tirtayasa, Banten, \\ Indonesia
}

\begin{abstract}
Abstrak
Tujuan dari penelitian ini adalah untuk menganalisis pengaruh standar organisasi dan tata kerja, partisipasi anggaran dan pengendalian anggaran terhadap perilaku dysfunctional pelaksana Satuan Kerja Perangkat Daerah (SKPD) dalam pelaksanaan otonomi daerah dan desentralisasi pada tingkat pemerintah Kabupaten dan Kota di wilayah Provinsi Banten. Populasi terdiri dari para pejabat SKPD pada pemerintahan Kabupaten dan Kota tersebut. Dengan teknik pengambilan purposive sampling, maka dipilih sampel dengan kriteria pejabat SKPD yang terlibat dalam rekontruksi rancangan dan penggunaan Sistem Informasi Keuangan Daerah (SIKD). Dengan demikian, yang menjadi responden dalam penelitian ini adalah kepala badan, kepala dinas, kepala bidang, kepala seksi bagian keuangan, pembukuan dan penyusunan anggaran pada Pemerintahan Daerah Kabupaten/Kota Propinsi Banten. Sedangkan untuk analisis data digunakan program SmartPLS (Partial Least Square).Hasil penelitian ini menunjukkan bahwa standar organisasi dan tata kerja (SOTK), partisipasi anggaran dan pengendalian anggaran berpengaruh terhadap perilaku dysfunctional pada SKPD pemerintahan daerah pada kabupaten/kota di provinsi Banten. Semakin baik standar operating tata kerja SKPD maka akan mengurangi perilaku Dysfunctional.Semakin banyak keterlibatan SKPD dalam penyusunan anggaran, maka perilaku Dysfunctional akan dapat dihindari. Perilaku Dysfunctional dapat dihindari dengan pengendalian anggaran untuk tujuan yang positif.
\end{abstract}

Kata kunci: Partisipasi Anggaran, Pengendalian Anggaran, Struktur Organisasi Tata Kerja, Perilaku Dysfunctional

\section{MANAGEMENT CONTROL SYSTEM AND DYSFUNCTIONAL BEHAVIOR SATUAN KERJA PERANGKAT DAERAH AT BANTEN PROVINCE}

\begin{abstract}
This study aims to investigate the impact of standard operating procedures, budget participation, and budget control on dysfunctional behaviour of Satuan Kerja Perangkat Daerah (SKPD) at Banten Province. The population of this study is the chief officers at all districts and cities in Banten area. We select the officers who involved in reconstructing the
\end{abstract}


planning and using SistemInformasiKeuangan Daerah (SIKD), which consist of the head of department, the head of field, the head of financial, accounting and budget planning division.The data were collected by using questioner and analyzed by using SmartPLS (Partial Least Square).The results show that those management control tools have an impact on dysfunctional behavior of SKPD. We found that a better standards operating procedures of SKPD could reduce the dysfuctional behavior. The more involvement of SKPD in budget planning, the more dysfunctional behavior could avoid. Finally, dysfunctional behavior could decrease by using budget control for positive intention.

Keywords: budget participation, budget control, standards operating procedures, dysfunctional behavior

\section{PENDAHULUAN}

Penerapan otonomi daerah yang diatur dalam Undang-Undang Nomor 32 dan Undang-Undang Nomor 33 Tahun 2004 tentang Otonomi Daerah dan Perimbangan Keuangan Pusat dan Daerah bertujuan untuk memberikan keluasan pada daerah untuk menyelanggarakan pemerintahannya. Harapannya dengan penerapan otonomi daerah ini dapat tercipta sistem pemerintahan yang bersih dan mampu meningkatkan akuntabilitas pemerintah daerah. Untuk itu pemerintah dituntut untuk dapat membangun sistem pengendalian manajemen pemerintahan daerah yang baik, sehingga mampu menciptakan akuntabilitas publik yang bermutu dalam rangka mewujudkan sistem pemerintahan daerah yang bersih. Salah satu fungsi dari sistem pengendalian manajemen pada pemerintah daerah adalah sebagai pemonitor kinerja Satuan Kerja Perangkat Daerah (SKPD). Pengawasan kinerja ini meliputi pengawasan terhadap perilaku pegawai pada SKPD terutama pada level manajerial. Penerapan sistem pengendalian manajemen pada pemerintahan daerah dapat diukur dengan melihat bagaimana partisipasi anggaran dilakukan, penerapan pengendalian anggarannya, dan struktur organisasi dan tata kerja (SOTK) yang diterapkan pada SKPD tersebut. Pengawasan perlu dilakukan karena pejabat SKPD ada kemungkinan untuk berperilaku menyimpang atau yang disebut sebagai perilaku dysfunctional.

Perilaku dysfunctional dapat tercermin dalam budgetary slack dan manipulasi ukuran kinerja. Langevin dan Mendoza (2013) menganalisis tentang pengaruh sistem pengendalian manajemen dalam mengurangi tindakan tidak etis yang terwujud dengan munculnya budgetary slack dan manipulasi data. Sebelumnya, Soobaroyen (2006) menguji keterkaitan antara sistem pengendalian manajemen dan perilaku dysfunctional. Hasil penelitian tersebut membuktikan bahwa terdapat hubungan antara sistem pengendalian manajemen dan perilaku dysfunctional. Dalam penelitiannya tersebut sistem pengendalian manajemen meliputi standar prosedur pengoperasian, partisipasi anggaran, ketergantungan pada pengukuran kinerja akuntansi. Penelitian ini mengacu pada model Soobaroyen (2006) tersebut, namun analisis dilakukan pada obyek organisasi sektor publik. Analisis ditujukan untuk mengetahui apakah sistem pengendalian manajemen yang terwujud dalam SOTK, partisipasi anggaran dan pengendalian anggaran berpengaruh pada perilaku dysfunctional.Menindaklanjuti penelitian Wiyantoro dan Ismail (2012), penelitian ini mengambil obyek penelitian seluruh SKPDSKPD di Kabupaten dan Kota di wilayah provinsi Banten. Penelitian sebelumnya hanya mengambil sampel khusus pada Dinas Pendidikan saja. 


\section{TINJAUAN PUSTAKA}

\section{Otonomi Daerah dan Desentralisasi}

Sejalan dengan kebijakan desentralisasi, kewenangan penyelenggaraan pemerintah juga dilakukan desentralisasi fiskal yang kebijakannya dituangkan melalui Undang-Undang Nomor 32 dan 33 tahun 2004. Kebijakan desentralisasi fiskal tercermin dalam hal perimbangan keuangan antara Pusat dan Daerah. Dalam kebijakan tersebut mengandung cakupan yang sangat luas yaitu bahwa dalam pelaksanaan Otonomi Daerah ingin diwujudkan suatu tatanan penyelenggaraan pemerintah khususnya dari sisi keuangan yang lebih baik.

\section{Teori Keperilakuan}

Perkembangan penelitian keperilakuan dalam akuntansi berkembang seiiring dengan berkembangnya pendekatan kontijensi (contigency approach). Bahkan Otley (2016) mengatakan bahwa dapat dikatakan semua penelitian akuntansi manajemen menggunakan pendekatan kontinjensi. Pendekatan ini muncul ketika ditemukan banyaknya kelemahan dalam penggunaan pendekatan universal dalam riset keprilakuan. Penelitian-penelitian yang dilakukan dengan pendekatan kontijensi bertujuan untuk mengidentifikasi variabel-variabel yang berpengaruh pada perancangan dan penerapan sistem pengendalian manajemen. Berbagai konsep perilaku organisasi harus tercermin pada kondisi situasional atau hal-hal yang kontijensi/kebetulan (Robbins, 1996).Di Indonesia sendiri penelitian akuntansi keperilakuan pada organisasi sektor publik masih jarang dilakukan, namun beberapa sudah mulai bermunculan (Yuhertiana et al., 2015).

Lubis (2010) menjelaskan bahwa perkembangan akuntansi keperilakuan sangat dipengaruhi oleh teori dasar dalam perilaku, yaitu bidang sosiologi, sosiologi-psikologi, dan psikologi. Bidang psikologi mempelajari perilaku manusia itu sendiri, bidang sosial-psikologi mempelajari hubungan manusia dengan manuasi lainnya dan bidang sosial mempelajari hubungan manusia dengan masalah kemasyarakatan. Sementara itu menurut Shields dan Young (1993) berpendapat teori keperilakuan khususnya perilaku organisasi dan teori agensi yang mendasarkan pada ilmu ekonomi mendominasi penelitian akuntansi keperilkuan. Dalam penelitian mendasarkan pada teori yang pertama yaitu pendekatan perilaku organisasi.

Menurut Robbins (1996), terdapat empat cara yang dapat membentuk perilaku yaitu melalui penguatan positif, penguatan negatif, hukuman dan pemunahan. Penguatan positif dilakukan apabila suatu respon diikuti dengan sesuatu yang menyenangkan. Penguatan negatif terjadi apabila suatu respon diikuti oleh dihentikannya sesuatu yang tidak menyenangkan. Sedangkan hukuman akan mengakibatkan sebuah kondisi yang tidak menyenangkan untuk menyingkirkan suatu perilaku yang tidak diinginkan. Sementara itu, pemunahan dilakukan untuk meyingkirkan penguatan apapun yang mempertahankan suatu perilaku.

\section{Perilaku Dysfunctional}

Perilaku disfungsional didefinisikan sebagai perilaku yang dilakukan oleh individu atau sekelompok individu yang memiliki konsekuensi negatif bagi individu yang lain, kelompok lain atau organisasi itu sendiri (Griffin dan Lopez, 2005). Perilaku disfungsional tersebut dilakukan dengan tujuan untuk mencapai kepentingan individu atau kelompok individu tersebut. Sedangkan Jaworski dan Young (1992) mendefinisikan perilaku disfungsional sebagai suatu tindakan yang dilakukan dengan usaha kurang maksimal yaitu dengan memanipulasi unsur-unsur sistem pengendalian untuk tujuan yang dikehendaki.

Binberg et al. (2003) menjelaskan beberapa bentuk perilaku disfungsional berikut ini.

1. Smoothing, merupakan bentuk perilaku disfungsional dengan melakukan penghalusan. Tindakan ini dilakukan dengan mengubah data perencanaan awal dan mengubah 
aktivitas-aktivitas riil dalam organisasi sehingga manipulasi yang dilakukan menjadi tidak terihat.

2. Biasing and focusing, merupakan bentuk perilaku disfungsional dengan melakukan pembiasan dan pemfokusan. Tindakan ini dilakukan misalnya dengan pembiasan terhadap pemilihan informasi. Contohnya, manajer memilih informasi yang paling baik dan sesuai dengan keadaan yang dapat menguntungkan manajer tersebut untuk disampaikan pada atasannya. Perilaku ini dapat mengakibatkan informasi yang diterima oleh atasan akan menjadi bias.

3. Filtering, merupakan bentuk perilaku disfungsional dengan melakukan penyaringan informasi. Contoh tindakan ini adalah ketika seorang bawahan menyembunyikan sebuah informasi dari atasannya, karena dia berpikir jika atasan mengetahui informasi tersebut maka akan dapat digunakan sebagai jalan untuk menghambat keberhasilan bawahan.

4. Illegal acts or falsification, merupakan bentuk perilaku disfungsional dengan melakukan perbuatan yang melanggar aturan atau pemalsuan. Contohnya, seseorang dengan sengaja memalsukan dokumen atau laporan-laporan dengan cara melanggar aturan organisasi.

\section{Tinjauan Penelitian Sebelumnya}

Berikutiniadalahpenelitianterdahulu yang dapatdilihat pada tabel 1 dibawahini:

\section{Tabel 1}

Uraian tentang Penelitian Terdahulu dan Pembaharuan Penelitian

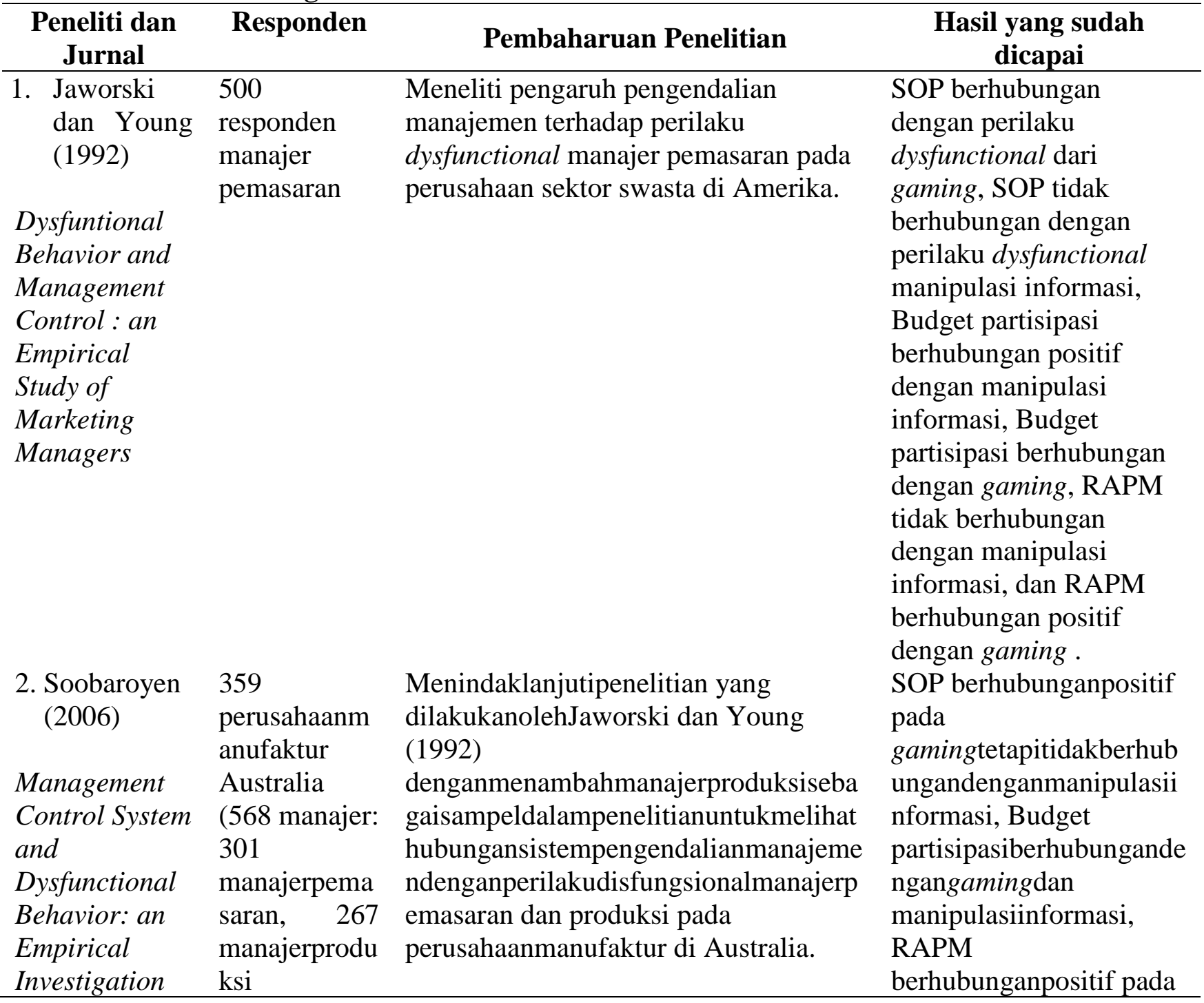


3. Wiyantoro dan Ismail (2012)

\begin{tabular}{|c|c|}
\hline $\begin{array}{l}280 \text { pejabat } \\
\text { dinas } \\
\text { pendidikan di } \\
\text { tingkat } \\
\text { Kabupaten } \\
\text { dan Kota } \\
\text { yang terlibat } \\
\text { dalam } \\
\text { penyusunan } \\
\text { anggaran. }\end{array}$ & $\begin{array}{l}\text { Penelitian ini menambahkan variabel } \\
\text { budaya nasional sebagai variabel yang } \\
\text { memoderasi pengaruh sistem } \\
\text { pengendalian manajemen terhadap } \\
\text { perilaku dysfunctional. }\end{array}$ \\
\hline
\end{tabular}

praktekmanipulasiinform

asi dan gaming.

Partisipasi anggaran, pengendalian anggaran dan SOP berpengaruh terhadap perilaku dysfunctional. Untuk budaya nasional, hanya ditemukan pengaruh moderasi budaya nasional pada hubungan pengendalian anggaran dan perilaku dysfunctional.

\section{Pengaruh Struktur Organisasi Tata Kerja (SOTK) terhadap Perilaku Dysfunctional}

Standard Operating Procedure (SOP) merupakan aturan-aturan yang dijadikan acuan bagi manajer untuk berkegiatan pada departemennya (Soobaroyen, 2006). Pada sektor pemerintahan, SOP dituangkan dalam Struktur Organisasi dan Tata Kerja (SOTK). SOTK ini harus dijadikan panduan bagi pegawai SKPD dalam menjalankan tugasnya dan acuan pengambilan keputusan pada tingkat manajerial sebuah SKPD. Oleh karena itu, SOTK sebaiknya dirancang dengan jelas dan mudah dipahami. Menurut Soobaroyen (2006), manajer akan cenderung berperilaku disfungsional ketika SOP yang diterapkan sebagai pengendalian aktivitas dibuat sangat rumit.

$\mathrm{H}_{1}$ : Tingkat kerumitan standar organisasi dan tata kerja berpengaruh terhadap perilaku dysfunctional

\section{Pengaruh Partisipasi Anggaran (Budgetary Participation) terhadap Perilaku Dysfunctional}

Partisipasi anggaran telah diteliti secara luas, namun masih tetap ada dalam agenda penelitian (Derfuss, 2016). Hal ini menandakan partisipasi anggaran masih menarik perhatian peneliti untuk menginvestigasinya. Keragaman dan kegunaan yang situasional dari pengganggaran dalam berbagai organisasi (Amans et al., 2015) menjadikan topik pengganggaran masih terus menarik perhatian peneliti. Selain itu penelitian terdahulu kebanyakan dilakukan di negara maju dengan sektor privatnya (Jermias dan Yigit, 2013; Noor dan Othman, 2012). Hal tersebut menciptakan gap dalam literatur akuntansi manajemen pada negara berkembang (Scapens dan Bromwich, 2010), terutama untuk penelitian pada sektor publik (Kihn, 2010). Penelitian Lukka (2003) menemukan konsep penganggaran yang dapat menyebabkan kecenderungan manajer untuk berperilaku disfungsional. Penyimpangan tersebut dilakukan dengan cara menciptakan pembiasan dalam membuat perencanaan. Pembiasan yang dilakukan adalah dengan memberi laporan yang melebihi kinerja yang seharusnya menjadi target dalam anggaran. Dengan kecenderungan ini maka partisipasi anggaran dapat dimanfaatkan oleh manajer untuk melakukan penyimpangan ini. Dari temuan ini dapat disimpulkan bahwa partisipasi anggaran dapat dimanfaatkan oleh pelaksanan SKPD untuk melakukan penyimpangan.

$\mathrm{H}_{2}$ : Partisipasi anggaran berpengaruh terhadap perilaku dysfunctional 


\section{PengaruhPengendalian Anggaran terhadapPerilakuDysfunctional}

Penelitian tentang Reliance on Accounting Performance Measurement (RAPM) berfokus pada cara manajer dalam menggunakan informasi akuntansi dan informasi lain yang mereka peroleh dalam proses mengendalikan para bawahan dalam mempertanggungjawabkan kinerja mereka (Otley, 2016). Sementara itu, Hopwood (2002) mengembangkan penelitian yang mengkaji tentang gaya penilaian kinerja yang dimiliki pejabat-pejabat pada sektor pemerintahan. Hasilnya mengindikasikan bahwa pengendalian anggaran yang tinggi cenderung akan mendorong para pejabat untuk berperilaku positif. Riset yang dilakukan Langevin dan Mendoza (2013) memberikan penjelasan bahwa karakteristik keadilan pada sistem pengendalian manjemen dapat mengurangi perilaku dysfunctional. Mereka menggunakan kesenjangan anggaran dan manipulasi data sebagai indikator adanya penyimpangan perilaku.

$\mathrm{H}_{3}$ : Pengendalian anggaran berpengaruh terhadap perilaku dysfunctional gambar 1.

Dari pengembangan hipotesis di atas maka model penelitiandigambarkan seperti pada

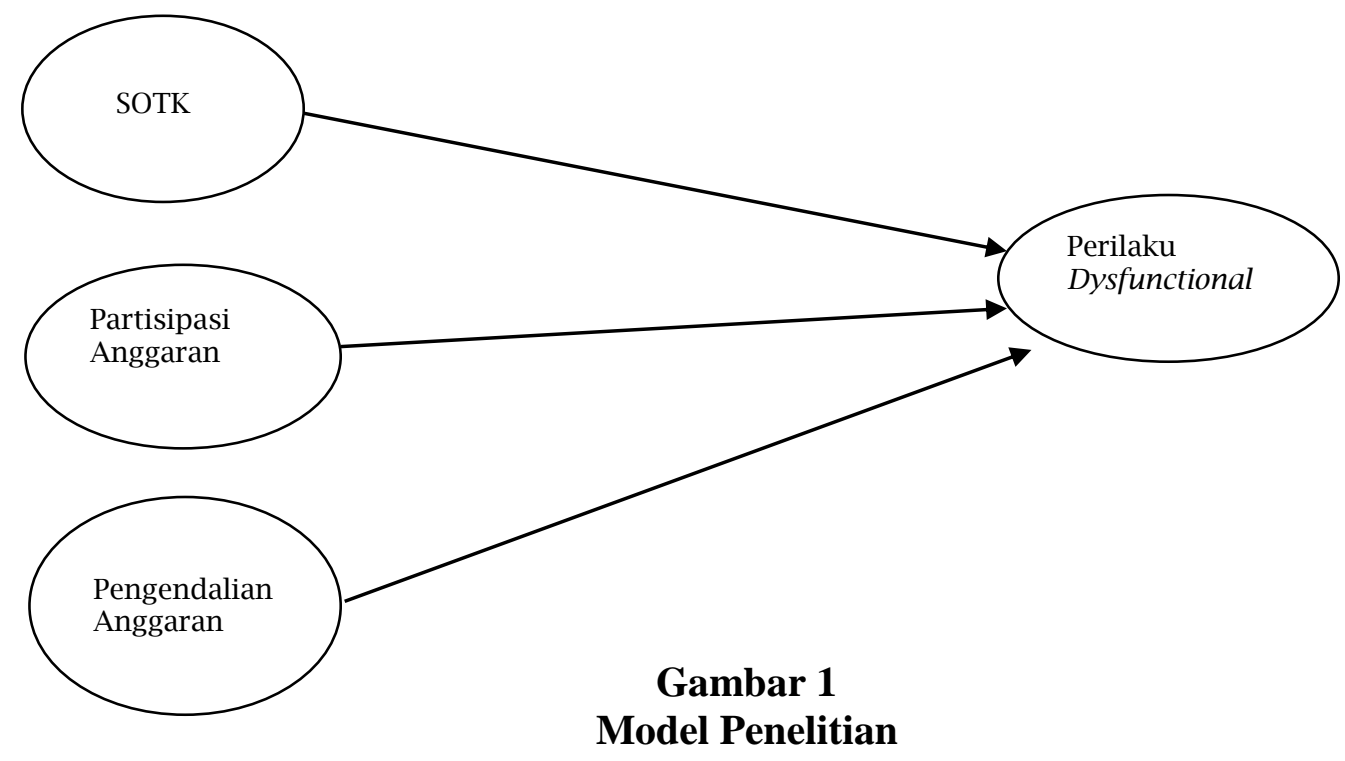

Sumber: Soobaroyen (2006) dan Wiyantoro dan Ismail (2012)

\section{Populasi dan Teknik Penyampelan}

\section{METODE}

Obyek dalam penelitian ini adalah seluruh SKPD pada Kabupaten dan Kota di wilayah Provinsi Banten yang terdiri dari empat kota (Kota Serang, Kota Tangerang, Kota Tangerang Selatan dan Kota Cilegon) dan empat Kabupaten (Kabupaten Serang, Kabupaten Tangerang, Kabupaten Pandeglang dan Kabupaten Lebak). Sehingga yang menjadi populasi dalam penelitian adalah para pejabat yang menduduki level manajerial pada SKPD-SKPD tersebut. Teknik penyampelan yang dipilih adalah purposive sampling, dengan kriteria sampelnya adalah pejabat yang terlibat dalam rekontruksi rancangan dan penggunaan Sistem Informasi Keuangan Daerah (SIKD). Dengan demikian yang menjadi responden dalam penelitian ini adalah kepala badan/dinas, kepala bidang, dan kepala seksi bagian keuangan, 
pembukuan dan penyusunan anggaran. Dengan asumsi tingkat respon sebesar 20\%, untuk mencapai target kuesioner terisi sebanyak 140 buah maka kuesioner yang dikirim sebanyak 700 kuesioner ( 8 kabupaten/kota x 10 dinas tiap kabupaten/kota x antara 8 sampai dengan 9 pejabat tiap dinas).

\section{JenisdanProsedurPengumpulan Data Penelitian}

Jenis data yang digunakan dalam penelitian ini adalah data primer. Pengumpulan data dilakukan dengan instrumen kuesioner, yang dikirimkan secara langsung kepada responden sesuai dengan kriteria sampel pada SKPD-SKPD delapan Kota/Kabupaten di wilayah provinsi Banten.Kuesioner-kuesioner yang telah diisi dikumpulkan kembali oleh peneliti pada waktu yang telah dijanjikan. Rata-rata responden diberi waktu satu minggu untuk pengisian kuesioner.

\section{VariabelPenelitiandanPengukurannya}

Dalam upaya untuk mendapatkan hasil kuesioner yang valid dan reliabel, maka disusun item-item kuesioner berdasarkan literatur terkait pada studi sebelumnya. Kuesioner terdiri dari dua bagian, yaitu informasi demografi responden pada bagian pertama, dan pada bagian kedua tentangvariabelpenelitian yang meliputiStandard Organisasidan Tata Kerja, Partisipasianggaran, PengendalianAnggaran , danperilakuDysfunctional. Indikator yang digunakan untuk mengukur Standard Organisasidan Tata Kerja (SOTK), mengacu pada indikator yang digunakan oleh Soobaroyen (2006) sebanyak 4 (empat) indikator. Partisipasi anggaran (BP/budget participation) menggunakan indikator yang digunakan oleh Soobaroyen (2006) sebanyak 4 (empat) indikator.PengendalianAnggaran (PA) menggunakan 4 (empat) indikator yang digunakan Soobaroyen (2006). PerilakuDysfunctional (DB) sebanyak 6 (enam) indikator. Pernyataan dalam kuesioner menggunakan pengukuran skala Likert 1 sampai 5. Skor 1 mewakili pendapat responden "sangat tidak setuju" dan berturut-turut sampai dengan skor 5 menunjukkan pendapat "sangat setuju" terhadap sebuah pernyataan dalam kuesioner.

\section{TeknikPengolahan Data}

Data yang telah terkumpul melalui kuesioner kemudian diolah dengan menggunakan software SmartPLS. Alat ini merupakan salah satu model pengolahan untuk structural Equation Model (SEM). Pengolahan dengan model Partial Least Square (PLS) lebih bersifat predictive model. Alat analisis ini digunakan untuk menjelaskan hubungan antara varaibel laten. Selain itu, dapat juga digunakan untuk menganalisis konstruk yang dibentuk dengan indikator yang bersifat refleksif dan formatif. Selanjutnya, sekaligus dapat dilakukan analisis konstruk yang dibentuk dengan indikator.

\section{HASIL DAN PEMBAHASAN}

Pengumpulan data dilakukan pada obyek penelitian yaitupejabatpemda (SKPD) yang berada pada 4 Kabupaten dan 4 Kota di wilayah ProvinsiBanten dengan total jumlah 700 kuesioner. Namun, sampai dengan akhir waktu yang ditentukan hanya sejumlah 210kuesioner yang kembali. Dengan demikian penyebaran kuesioner dalam penelitian ini memiliki tingkat respon sebesar 30\%. Setelah melalui proses pengecekan kelengkapan pengisian, hanya 192 kuesioner yang dapat digunakan. 


\section{Statistik Deskriptif Variabel Penelitian}

Untuk variabel Standar organisasi dan tata kerja (SOTK), data yang diperoleh dari variabel perlu dilakukan proses proses recode (skala yang tinggi menunjukkan SOTK yang sangat rumit, skala yang rendah menunjukkan SOTK yang sangat sederhana). Setelah dilakukan proses recode ini, dapat dilihat jawaban responden terhadap variabel ini cukup bervariasi. Jawaban responden rata-rata sebesar 15,29 dengan standar deviasi sebesar 2,056. Hal ini menunjukkanbahwa standar prosedur pengoperasian cenderung tidak terlalu rumit dan sederhana dalam arti standar prosedur pengoperasian mudah dipahami oleh SKPD (mudah dilakukan oleh SKPD).

Pengukuran indikator-indikator pada variabel Partisipasi Anggaran (BP), nilai yang tinggi menunjukkan partisipasi SKPD dalam penyusunan anggaran sangat banyak, sedangkan skor yang rendah menunjukkan partisipasi SKPD dalam penyusunan anggaran sangat sedikit. Jawaban yang diberikan oleh responden terhadap variabel ini menunjukkan bahwa jawaban rata-rata sebesar 14,92 dengan standar deviasi 2,279 hal ini berarti partisipasi SKPD dalam penyusunan anggaran cukup banyak.

\section{Tabel 2}

Descriptive Statistics

\begin{tabular}{|c|c|c|c|c|c|}
\hline & $\mathrm{N}$ & $\begin{array}{l}\text { Minimu } \\
\mathrm{m}\end{array}$ & $\begin{array}{c}\text { Maximu } \\
\mathrm{m}\end{array}$ & Mean & $\begin{array}{c}\text { Std. } \\
\text { Deviation }\end{array}$ \\
\hline $\begin{array}{l}\text { SOTK } \\
\end{array}$ & 192 & 5 & 20 & 15.29 & 2.056 \\
\hline $\mathrm{BP}$ & 192 & 9 & 20 & 14.92 & 2.279 \\
\hline PA & 192 & 8 & 19 & 15.46 & 1.634 \\
\hline DB & 192 & 14 & 29 & 23.17 & 1.941 \\
\hline $\begin{array}{l}\text { Valid N } \\
\text { (listwise) }\end{array}$ & 192 & & & & \\
\hline
\end{tabular}

Pengukuran indikator-indikator pada variabel pengendalian anggaran, skor yang tinggidapat diartikan bahwaevaluasi yang dilakukan atasan terhadap kinerja manajer sangat banyak. Dengan kata lain skor yang tinggi mengindikasikan kinerja yang dilakukan oleh SKPD sangat baik. Sebaliknya, skor yang rendah mengindikasikansedikitnya evaluasi yang dilakukan oleh atasan terhadap kinerja SKPD sangat sedikit (menunjukkan buruknya kinerja yang SKPD ). Jawaban yang diberikan responden terhadap variabel ini menunjukkan bahwa rata-rata jawaban responden sebesar 15,46 dengan standar deviasi 1,634 hal ini berarti pengevaluasian atasan terhadap kinerja SKPD banyak atau kinerja yang dilakukan oleh SKPD baik. Pengukuran indikator-indikator pada variabel perilaku dysfunctional gaming (DB), skoryang tinggi menunjukkan bahwa responden tidak pernah melakukan perilaku disfungsional, sedangkan skor rendah mengindikasikan responden sangat sering melakukan perilaku disfungsional. Skor jawaban responden pada variabel ini menunjukkan bahwa ratarata jawaban sebesar 23,17 dengan standar deviasi 1,941 hal ini berarti SKPD kadang-kadang melakukan perilaku dysfunctional (jarang melakukan perilaku dysfunctional).

\section{Pengujian Outer Loading}

Pengujian outer loading pada penelitian ini dilakukan melalui tiga tahap. Jika outer loading setiap konstruk variabel penelitian yang kurang dari 0.5 maka indikator konstruk variabel tersebut penelitian harus dieliminasi . Tiga tahap tahap pengujian outer loading dalam penelitian ini terdiri dari; 1) Tahap sebelum eliminasi, 2) Tahap setelah eliminasi pertama, dan 3) Tahap setelah eliminasi kedua. 


\section{Tahap sebelum eliminasi}

Dilihat dari gambar 2 menunjukkan nilai outer loading semua indikator variabel SOTK di atas 0,5 dengan demikian indikator untuk variabel SOTK tidak ada yang dieliminasi karena nilai outer loadingnya lebih dari 0,5. Nilai outer loading indikator variabel Budget Partisipasi (BP) ternyata ada yang di bawah 0,5 yaitu indikator BP1 dimana nilai outer loading sebesar 0,357. Nilai outer loading indikator variabel Pengendalian Anggaran (PA) ada yang dieliminasi karena nilai outer loadingnya di bawah 0,5 yaitu PA4 nilai outer loading sebesar 0,357dengan demikian indikator untuk variabel PA4 dieliminasi. Nilai outer loading variabel perilaku Dysfunctional (DB) ternyata ada yang di bawah 0,5 yaitu DBGA2 nilai outer loadingnya sebesar 0,450 , DBIN1 nilai outer loadingnya sebesar 0,267 , dan DBIN3 nilai outer loadingnya sebesar -0,291. Dengan demikian indikator variabel perilaku Dysfunctional (DB) yang harus dielimansi yaitu indikator DBGA2, DBIN1 dan DBIN3.

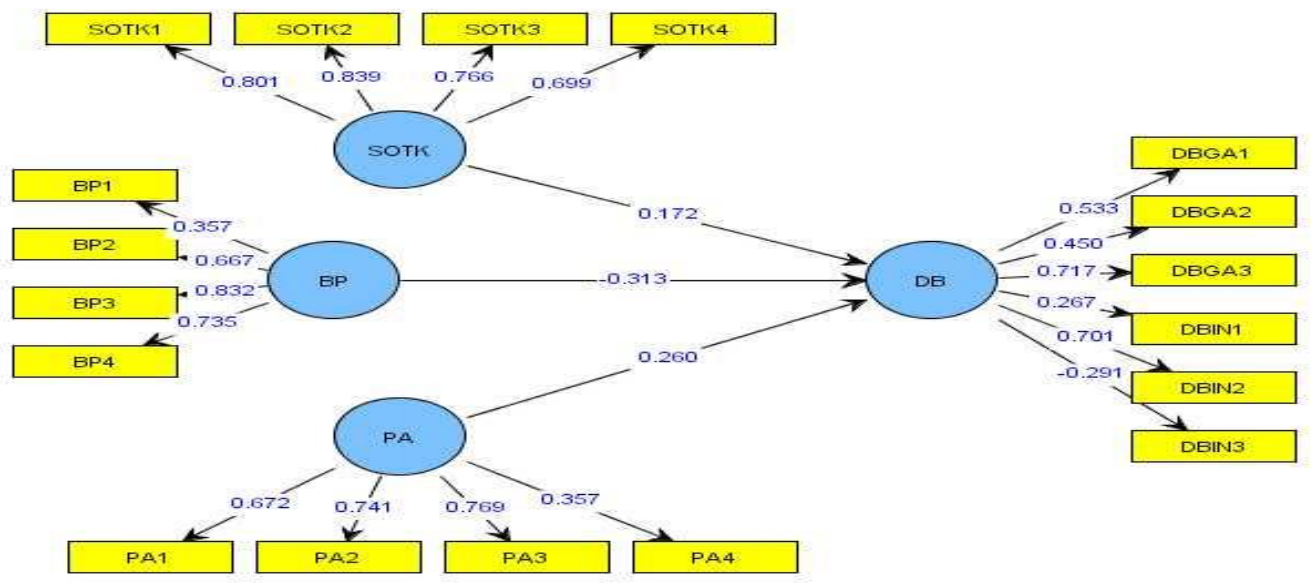

\section{Gambar 2 \\ Full Model Penelitian Sebelum Eliminasi}

\section{Tahap Setelah Eliminasi Pertama}

Dilihat dari gambar 3 nilai outer loading semua indikator variabel SOTK di atas 0,5 dengan demikian indikator untuk variabel SOTK tidak ada yang dieliminasi karena nilai outer loadingnya lebih dari 0,5. Nilai outer loading indikator variabel Budget Partisipasi (BP) ternyata masih ada yang di bawah 0,5 yaitu indikator BP2 dimana nilai outer loading sebesar 0,499 dengan demikian indikator BP2 dieliminasi. Nilai outer loading semua indikator variabel Pengendalian Anggaran (PA) di atas 0,5 dengan demikian indikator untuk variabel PA tidak ada yang dieliminasi karena nilai outer loadingnya lebih dari 0,5 . Nilai outer loading variabel perilaku Dysfunctional (DB) tidak ada yang di bawah 0,5 akan tetapi nilai validy dan realibity penelitian ini masih belum memenuhi dengan demikian untuk mengantisipasi agar nilai validity dan reliability baik maka DBGA1 dieliminasi meskipun di atas 0,5 yaitu nilai outer loadingnya paling kecil 0,577 dibanding dengan nilai outer loading indikator DB lainnya. Dengan demikian indikator DBGA1 dieliminasi. 


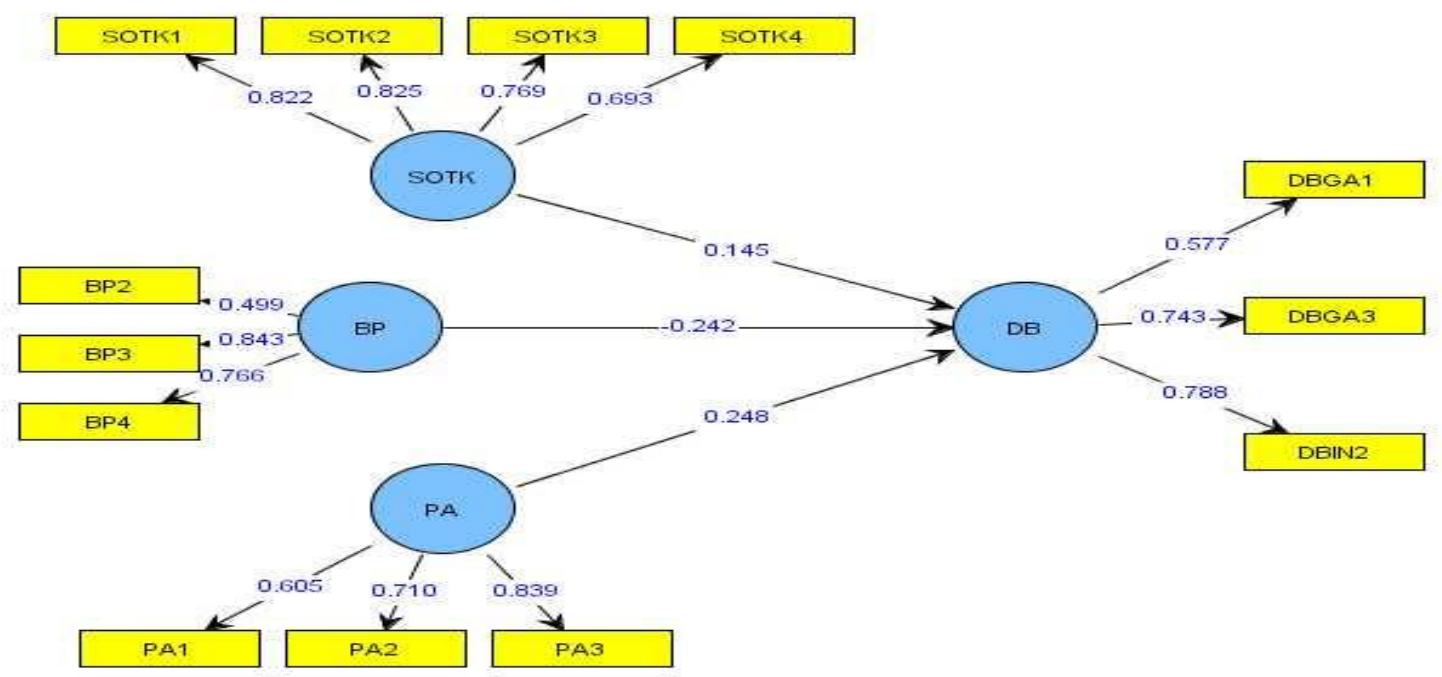

Gambar 3

Full Model Penelitian Setelah Eliminasi Pertama

\section{Tahap Setelah Eliminasi Kedua}

Dilihat dari gambar 4 semua indikator pada semua konstruk variable penelitian nilai outer loadingnya di atas 0,5 dengan demikian semua indikator pada semua konstruk variabel pada tahap elimanasi kedua tidak ada yang dieliminasi.

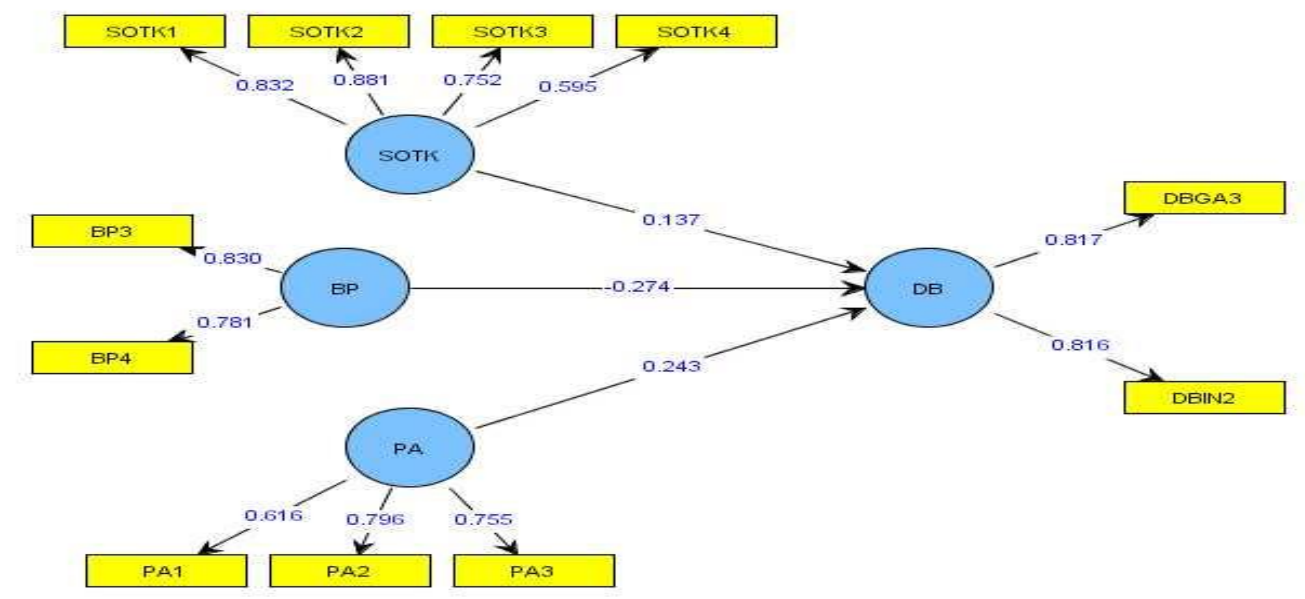

\section{Gambar 4}

\section{Full Model Penelitian Setelah Eliminasi Kedua}

\section{Uji Kualitas Data}

Tahap eliminasi outer loading pada semua indikator variabel penelitian telah dilakukan yang mempengaruhi terhadap kualitas data yaitu validitas dan reliabilitas.

\section{Uji Validitas}

Pengujian validitas data menggunakan softwareSmartPLS dengan Outer Model. Untuk menilai validitas masing-masing variabel adalah dengan melihat Convergent validity yang 
dapat diukur dari nilai average variance extracted (AVE). Variabel dianggap valid jika nilai AVE lebih besar dari 0,5.Dilihat dari tabel 3, nilai AVE setiap variabel diatas 0.5. hal ini daat disimpulkan bahwa setiap konstruk yang digunakan dalam penelitian ini memiliki validitas yang baik.

Tabel 3

Average Variance Extracted (AVE)

\begin{tabular}{cc}
\hline \multicolumn{2}{c}{ Average variance extracted (AVE) } \\
\hline SOTK & 0.607 \\
BP & 0.515 \\
PA & 0.525 \\
DB & 0.502 \\
\hline
\end{tabular}

\section{Uji Reliabilitas}

Pengujian reliabilitas dalam penelitian ini dilakukan dengan melihat nilai composite reliability yang didapat dari output PLS. Jika nilai composite reliability-nya diatas 0.7 , maka data dikatakan reliabel (Ghozali; 2006). Pada tabel 4 dapat dilihat bahwa nilai composite reliabilitydari semua konstruk ada diatas 0,7. Hal ini menunjukkan bahwa internal consistency antar variabel mempunyai reliabilitas yang baik.

\begin{tabular}{cc}
\multicolumn{2}{c}{$\begin{array}{c}\text { Tabel } 4 \\
\text { Composite Reliability }\end{array}$} \\
\hline \multicolumn{3}{r}{ Composite Reliability } \\
\hline SOTK & 0.860 \\
BP & 0.753 \\
PA & 0.765 \\
DB & 0.748 \\
\hline
\end{tabular}

\section{PengujianHipotesisdanPembahasan}

Menurut Ghozali (2006: 38), inner model menggambarkan hubungan antar variabel laten. Output dari PLS terdapat hasil untuk Inner Weights, hasil ini akan menunjukkan nilai inner weights dari setiap hubungan langsung maupun tidak langsung. Nalai yang lebih besar dari nol menunjukkan bahwa model mempunyai nilai predictiverelevance. Untuk hasil inner model dari penelitian ini dapat dilihat pada tabel 5.

Tabel 5

Results for Inner Weights

\begin{tabular}{ccccc}
\hline & $\begin{array}{c}\text { Original sample } \\
\text { estimate }\end{array}$ & mean of subsamples Standard deviation T-Statistic \\
\hline $\begin{array}{c}\text { SOTK -> } \\
\text { DB }\end{array}$ & 0.137 & 0.267 & 0.156 & 2.881 \\
\hline
\end{tabular}




\begin{tabular}{lllll}
\hline BP -> DB & 0.274 & 0.322 & 0.087 & 3.134 \\
PA -> DB & 0.243 & 0.307 & 0.131 & 2.862 \\
\hline
\end{tabular}

Dari hasil analisis PLS,nilai R-square sebesar 0,6172. Hal ini dapat diartikan bahwa variabilitas konstruk perilaku disfungsionalyang mampu dijelaskan oleh variabilitas konstruk Standar Operating Tata Kerja, Budget Partisipasi, dan Pengendalian Anggaran adalah sebesar $61,72 \%$, sementara $38,28 \%$ dijelaskan oleh variabel-variabel lain yang tidak termasuk dalam model penelitian ini (Ghozali, 2006).

\section{PengujiandanPembahasanHipotesis 1}

Pada tabel 5 dapat dilihat nilai original sampel estimate SOTK $\rightarrow$ DB sebesar 0,137 dengan nilai T-statistik sebesar 2,811. Sehingga, dapat diambil kesimpulan bahwa hipotesis 1 didukung ( $\mathrm{t}$ statistik lebih besar dari t-tabel 1,96), SOTK berpengaruh terhadap perilaku Dysfunctional. Temuan ini sejalan dengan hasil Soobaroyen (2006) yang menemukan bahwa standar prosedur pengoperasian yang dirancang dengan rumit justru akan menyebabkan manajer untuk berperilaku disfungsional. Dalam konteksnya pada SKPD, semakin baik SOTK sebuah SKPD maka akan mengurangi perilaku Dysfunctional. Sebaliknya, SOTK yang lemah akan membuat pelaksana pada SKPD untuk melakukan perilaku Dysfunctional. Hasil ini juga mendukung penelitian Wiyantoro dan Ismail (2012).

\section{PengujiandanPembahasanHipotesis 2}

Nilai original sampel estimateuntuk hipotesis dua yaitu BP -> DB sebesar 0,274 dan Tstatistik sebesar 3,134 (lebih besar dari t-tabel, 1,96). Sehingga dapat diambil kesimpulan bahwa hipotesis 2 didukung yaitu budget partisipasi berpengaruh terhadap perilaku Dysfunctional. Sebagaimana temuan Lukka (2003) yang menyebutkan penyimpangan dalam tahap perencanaan anggaran dapat dilakukan salah satunya dengan pembiasan. Hasil statistik deskriptif jawaban responden menunjukkan bahwa partisipasi anggaran yang dilakukan oleh SKPD cukup tinggi, sedangkan hasil pengujian hipotesis menunjukkan variabel ini berpengaruh positif terhadap perilaku disfungsional. Sehingga dapat disimpulkan bahwa keterlibatan dalam penyusunan anggaranmampu meminimalkan kecenderungan untuk melakukan perilaku Dysfunctional.

\section{PengujiandanPembahasanHipotesis 3}

Nilai original sampel estimate untuk hipotesis 3 yaitu PA $\rightarrow$ DB sebesar 0,243 dan Tstatistik sebesar 2,862 (lebih besar dari t-tabel, 1,96). Hasil ini dapat disimpulkan bahwa hipotesis 3 didukung yaitu pengendalian anggaran berpengaruh terhadap perilaku Dysfunctional. Hasil ini mendukung temuan Wiyantoro dan Ismail (2012) yaitu pengendalian anggaran dapat mempengaruhi kecenderungan manajer SKPD untuk berperilaku disfungsional. Jawaban responden menunjukkan bahwa evaluasi yang dilakukan oleh atasan terhadap kinerja manajer banyak dengan kata lain kinerja SKPD baik. Hal ini mengindikasikan bahwa perilaku Dysfunctional dapat dihindari dengan pengendalian anggaran untuk tujuan yang positif. Akan tetapi perlu diwaspadai pula karena pengendalian anggaran dapat mengundang perilaku Dysfunctional apabila pengendalian anggaran digunakan untuk kepentingan pribadi. 


\section{SIMPULAN}

Dari hasil penelitian ini dapat disimpulkan bahwa ketiga alat system pengendalian manajemen yang terdapat pada SKPD-SKPD di Pemerintahan Daerah Kabupaten dan Kota wilayah Provinsi Banten yaitu Standar Organisasidan Tata Kerja (SOTK), partisipasi anggaran dan pengendalian anggaran berpengaruh terhadap perilaku dysfunctional pada manajerial SatuanKerjaPerangkat Daerah (SKPD). Implikasi dari penelitian ini khususnya bagi sektor pemerintahan adalah perilaku disfungsional dapat dikurangi kecenderungannya dengan menggunakan tiga alat sistem pengendalian manajemen. Hal tersebut dapat dilakukan dengan pertama, membuat SOTK yang tidak terlalu rumit sehingga mudah dipahami dalam penerapannya. Kedua, mendorong SKPD untuk berpartisipasi pada proses penyusunan anggaran secara efektif. Ketiga, atasan melakukan evaluasi kinerja manajer-manajer bawahannya untuk tujuan yang positif. Penelitian ini hanya memiliki tingkat respon dari responden sebesar 30\%. Rendahnya tingkat respon ini memang menjadi kendala umum bagi penelitian dengan menggunakan instrumen kuesioner, khususnya di Indonesia. Keterbatasan ini harus diperhatikan dalam menginterpretasi hasil penelitian ini. Bagi penelitian selanjutnya dapat menggunakan metode alternatif selain instrumen kuesioner. Misalnya dengan dengan metode eksperimen dan atau metode wawancara. Penulis mengucapkan terima kasih kepada Kementrian Ristek-Dikti yang telah memberikan pendanaan untuk melaksanakan penelitian ini.

\section{DAFTAR PUSTAKA}

Birnberg J.G., L. Turopolec, dan S.M. Young. 2003. "The Organizational Contex of Accounting". Accounting, Organizations and Society 28: 97-126

Derfuss, K. 2016. "Reconsidering The Participative Budgeting-Performance Relation: A Meta-Analysis Regarding The Impact of Level of Analysis, Sample Selection, Measurement, and Industry Influences". The British Accounting Review: 17-37.

Ghozali, I. 2006. Structural Equation Modeling, Metode Alternatif dengan Partial Least Square. Badan Penerbit Universitas Diponegoro, Semarang.

Griffin, R. W. Dan Y.P. Lopez. 2005. "Bad Behavior in Organizations: A Review and Typology for Future Research". Journal of Management 31 (6): 988-1005.

Hopwood, A.G. 2002. "An Empirical Study of the Role Accounting Data in Performance Evaluation". Empirical Research in Accounting (Supplement to Journal of Accounting Research) 10:156-605

Jaworski, B.J., dan S.M. Young. 1992. "Dysfunctional Behavior and Management Control: An Empirical Study of Marketing Managers". Accounting, Organization and Society 17 (1): $17-35$

Johnny J. dan F. Yigit. 2013. "Budgetary Participation in Turkey: The Effects of Information Asymmetry, Goal Commitment, and Role Ambiguity on Job Satisfaction and Performance". Journal of International Accounting Research 12 (1): 29-54. 
Kihn, L. A. 2010. "Performance outcomes in empirical management accounting research". International Journal of Productivity and Performance Management 59: 468492.

Langevin P. dan C. Mendoza. 2013. "How Can Management Control System Fairness Reduce Managers Unethical Behaviour?” European Management Journal 31: 202-222.

Lubis, A. I. 2010. Akuntansi Keperilakuan. Jakarta: Salemba Empat.

Lukka, K. 2003. "Budgetary Biasing in Organizations: Theoritical Framework and Empirical Evidence". Accounting, Organizations and Society 13: 205-218.

Noor, I. H. B. M., dan Othman, R. 2012. "Budgetary participation: How it affects performance and commitment". Accountancy Business and the Public Interest 1:53-73.

Otley, D. 2016. "The contingency theory of management accounting and control: 19802014”. Management Accounting Researchhttp://dx.doi.org/10.1016/j.mar.2016.02.001

Republik Indonesia. 2004. Undang-Undang No. 32 Tahun 2004. TentangPemerintah Daerah.

Republik Indonesia. 2004. Undang-Undang No. 33 Tahun 2004. TentangPerimbanganKeuanganAntaraPemerintahPusatdanPemerintah Daerah.

Robbins, S.P. 1996. Organizational Behavior: Concepts, Controversies, Appplications $7^{\text {th }}$. NJ: Prentice-Hall

Scapens, R. W., dan Bromwich, M. 2010. "Management accounting research: 20 years on”. Management Accounting Research 21: 278-284.

Shields, M. D., dan S. M. Young. 1993. "Antecedents and Consequences of Participative Budgeting: Evidence on the Effects of Asymmetrical Information". Journal of Management Accounting Research 5:265-280.

Soobaroyen Teerooven. 2006. "Management Control System and Dysfunctional Behavior: an Empirical Investigation". Accounting Behavior.

Wiyantoro, L.S. dan Ismail, T. 2012. "Management Control System, Dysfunctional Behavior and National Culture". Entrepreneurship and Business Entrepreneurship and Innovation for Global Competitiveness: Issues and Challenges. 23 April 2012. Universiti Malaysia Kelantan. Malaysia.

Yuhertiana I, S. Pranoto dan H. Priono. 2015. "Perilaku Disfungsional pada Siklus Penganggaran Pemerintah: Tahap Perencanaan Anggaran". Jurnal Akuntansi dan Auditing Indonesia 19 (1): 25-38. 